\title{
Unity and catholicity in the Korean Presbyterian Church: An ecumenical Reformed assessment
}

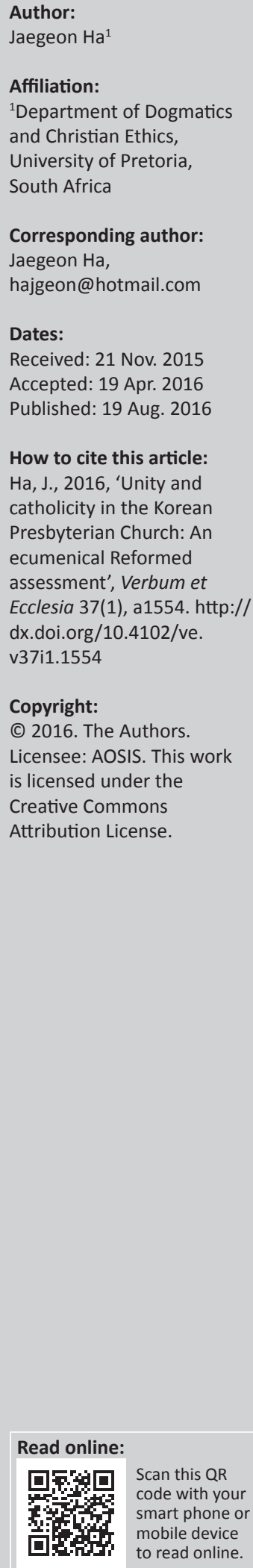

I attempt to find the main causes of the serious disunity in the Presbyterian Church in Korea (PCK), which started as one church but is now divided into more than 100 denominations, as well as a solution to promote the unity of the PCK. This attempt starts with an exegesis of Ephesians, with special reference to Ephesians 4:1-16, to understand the biblical principle on this matter. This article draws on a mature ecclesiology and a mature sense of unity as key concepts. After that, the history of the PCK disunity is briefly described, dealing with four major schisms. Based on this historical investigation, the disunity in the PCK is assessed. In addition, the weak sense of unity and weak ecclesiology of the PCK, which played a role in its disunity, are discussed in view of the confessions of faith, the ministry of the word and the Lord's Supper, and ecumenical efforts in relation to national and international ecumenical organisations. Lastly, contributory suggestions based on the mature sense of unity are offered to the PCK in particular and the Reformed family and all Christian churches in general.

Intradisciplinary and/or interdisciplinary implications: In my ecumenical Reformed intradisciplinary assessment of unity and catholicity in the PCK, which started as one church but is now divided into more than 100 denominations, I identify the main causes of serious disunity in the PCK, namely a weak sense of unity, immaturity and secularisation.

\section{Mature ecclesiology in Ephesians 4:1-16}

Paul exhorts the saints in Ephesus of his time and all the saints now, especially leading figures in the church, with a sense of urgency and a note of authority (Hoehner 2004:503), 'to live a life worthy of the calling you have received' (Ephesians 4:1). The calling is expounded in Ephesians 1-3 and is granted as God's blessing, grace, love and mercy to effect the believer's individual salvation and his or her union into the church, presented as one new person, one body of Christ, God's people, God's family and the holy temple, which all reflect the unity and catholicity of the church. 'A life worthy of the calling' implies that a believer's conduct should be balanced with his or her calling and that an individual believer's life should be balanced with that of the corporate body of believers.

The manner in which a life worthy of the calling should be lived is emphasised in Ephesians 4:2-3 through the seven graces of the Christian character to promote unity: lowliness, meekness, long-suffering, forbearing one another, love, endeavouring to keep the unity of the Spirit and peace. These seven graces that effect unity do not come of their own accord, but are ultimately brought about by the work of the Holy Spirit. Christians, especially the leading figures in the church, should live constantly asking and allowing the indwelling Spirit of God to guide and strengthen them, just like love in 1 Corinthians 13 and the fruit of the Holy Spirit in Galatians 5:16-26. Without the practice of these seven graces as essential practical guidelines, the unity of the church is far from becoming a reality.

Paul lists the sevenfold oneness of spiritual realities as theoretical, doctrinal basis and motivation for the unity of the church, focusing on the three persons of the Trinity in Ephesians 4:4-6: one body, one Spirit, one hope, one Lord, one faith, one baptism and one God the Father. The characteristics, origin, basis and motivation for the unity of the church are founded in and flow from the Triune God. Any thoughtless schismatic, sectarian conduct contrary to this unambiguous word of God constitutes disobedience to God, namely sin.

The unity and catholicity of the church are clarified doctrinally by the sevenfold oneness and should be practised visibly through the seven graces to unity by their recognition, education, confession and practical reality in the church. 1.Among the commentators on Ephesians are Andrew Lincoln (1990), Rudolf Schnackenburg (1991), Ernest Best (1998), Peter O'Brien
(1999), Harold Hoehner (2004, reprinted from 2002; 877 pages), Markus Barth (vol. 1. 2008; vol. 2. 2011, reprinted from 1974; 820 pages), Frank Thielman (2010) and Stephen Fowl (2012). 
Paul connects the donation of the gifts of Christ to each individual believer in Ephesians 4:7-10 and to specified groups of persons in 4:11 indicated in the list of gifts: apostles, prophets, evangelists, pastors and teachers. Ephesians 4:12-16 gives the fundamentally important message of God for attaining the unity of the church, the so-called mature sense of unity and mature ecclesiology.

The immediate purpose of the specifically gifted persons is the preparation of God's people. Through these persons' ministries, viz. their teaching, preaching and training, all believers are prepared or equipped for two subsequent goals: for the work of service (or ministry) and for the building up of the body of Christ, the church.

Paul indicates three aspects of the one and final goal, with a grammatical structure of three prepositions, 'to or into' (direction, goal) (Danker 2000:288-290), viz. 'until we all attain to ... to ... to ... ' in Ephesians 4:13.

The first aspect of the goal is the unity of the faith and of the knowledge of the Son of God, Jesus Christ. The second is a mature man. The final aspect is the measure of Christ's full stature (or maturity), seen as a mature man, which is more fully explicated.

Paul deals with the ultimate purpose of the final goal of attaining maturity on two levels, one for individual believers (Eph 4:14-15) and the other for the corporate body (Eph 4:16). Individual believers have to do away with spiritual childishness and immaturity and grow up into Christ, namely with Christlike maturity. Spiritual growth from immaturity to maturity is essential. Paul shows a most powerful, effective way to develop spiritual growth to unity among one another: 'speaking the truth in love'. The combination of 'speaking the truth' with 'in [or with] love' should be expressed and demonstrated in words and real conduct.

I coin the terms 'mature ecclesiology' and 'mature sense of unity' from Pauline ecclesiology in Ephesians 4:1-16. Individual believers and the corporate church are called not only to individual salvation, but also to the building up of the church until they attain to the unity and maturity of the church up to the measure of Christ's full stature. Doctrinal unity and practical maturity should be harmonised and balanced. Unity is directly connected with maturity in truth and love. The idea of 'unity and maturity in both truth and love', based on the sevenfold oneness and the seven graces to unity, is a core concept of Pauline ecclesiology in Ephesians $4: 1-16$ and is described as 'mature ecclesiology' and a 'mature sense of unity'.

Provided that the main cause of the big gap between the doctrine of the unity of the church and the reality of the serious disunity in the Presbyterian Church in Korea (PCK) in particular as well as in the Reformed family of churches is a 'weak sense of unity', according to Van der Borght (2010:1ff.), its solution can be found in the mature ecclesiology and mature sense of unity in Ephesians 4:1-16.

\section{Disunity of the Presbyterian Church in Korea}

The $\mathrm{PCK}^{2}$ was conceived with Presbyterian missionaries' translation of the books of the Gospel outside the country in the late nineteenth century, before the Korean government allowed foreign missionaries to do mission work in 1884. Missionaries from four Presbyterian churches, USA (northern), US (southern), Australia and Canada, organised the Presbyterian Council and worked together to establish one PCK. As a consequence, in 1902 theological education for pastors, as a preliminary stage of the Presbyterian Theological Seminary, could begin. In 1907 the first presbytery was organised and the first seven Korean pastors were ordained. In 1912 the first General Assembly (GA) of the PCK was held. In this way, the PCK started and gradually grew up as one church.

After the Japanese annexation (1910-1945), during and after the Korean Civil War (1950-1953), the PCK experienced three major schisms in 1952,1953 and 1959. Since 1979, non-mainline churches have experienced repeated schisms and reunions, like nuclear chain fission. As a result, it is said that the PCK has been divided into over 200 denominations, including over 20 denominations with the name Gae Hyuk (meaning 'reformed') Church.

One sociopolitical factor that played an important role in the disunity in the PCK was the Japanese annexation of Korea in 1910 and subsequent forced Shinto worship, with a meticulous plan. Regardless of opposition by most pastors of the PCK, Japan finally compelled the PCK to practise Shinto worship. In the 1938 the GA of the PCK decided on Shinto worship under the supervision of armed Japanese policemen. After this decision, the Presbyterian Theological Seminary at Pyeng Yang was closed and the pastors of the PCK were divided into three groups: active Shinto worshippers as Japanese agents asserting that Shintoism was not a religion but a national rite, passive unwilling worshippers and strong Protestants with a faith of martyrdom, asserting that Shintoism was absolute idolatry before God. Active advocates of Japanese imperialism could enjoy privileges with high positions of authority and power as social religious leaders, whereas active Protestants were persecuted, killed and put into jail. After liberation from Japan in 1945, active participants in Shintoism were able to retain their privileges as a leading group of the PCK. The pastors who were released from prison, who had been imprisoned because of their protest against Shintoism, suggested the basic reconstruction guideline of the PCK and campaigned for repentance and self-disciplinary suspension of the pastorate for a period of 2 months. Some presbyteries and individual churches responded obediently to the guideline, but among the active participants strong opposition was raised, saying that

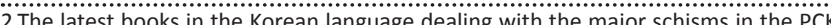
during the 1950 s are the works of Park Yong Gyu ([2004a] 2007, [2004b] 2006), Yang Nak Heung (2008) and Hur Soon Gil (2008: revision from 2002). Kang Min Su et al. Nak Heung (2008) and Hur Soon Gil (2008: revision from 2002). Kang Min Su et al.
(2015) and others compiled the history of the non-mainline Gae Hyuk Church from (2015) and others compiled the history of
the 1979 schism until the 2005 reunion. 
'whether in prison or in the church, the suffering was the same, and repentance can be made through a personal relationship with God'.

One element of conflict in the PCK at that time was theological education. After the closure of the Presbyterian Theological Seminary in 1938 due to Shintoism, the Chosun Theological Seminary was founded in 1940 by Korean pastors who did not take Shintoism seriously, but actively helped the Japanese policy and were theologically liberal, denying the infallibility of the Bible in the conservatives' eyes. After liberation the Chosun Seminary was the only theological seminary and was approved by the GA in 1946. An example that reflects the seriousness of liberal theology in the Chosun Seminary was an incident where 51 students opposed its liberal teaching and appealed to the GA. As a result of that incident, Pastor Han Sang Dong, who was a central figure among the released pastors and their followers, opened a new theological seminary, the Korea Theological Seminary, in the hope of restoring and purifying the PCK through teaching pastoral candidates conservative orthodox theology.

In 1952 the first major schism took place as a result of conflict between the so-called more pure party, composed of released pastors, and the so-called GA leaders' party, composed of mainly active advocates of Shintoism. The GA decided that it had nothing to do with the Korea Theological Seminary and that it was illegal for anyone, whether presbytery, church or pastors, to be involved with the Korea Seminary. The Gyeongnam Presbytery, composed of the released pastors and their followers, were severed by the GA because the pastors did not terminate their relationship with the Korea Theological Seminary. Therefore, Pastor Han Sang Dong and his followers started a new church, the Ko Shin Church, in 1952.

In 1953, the second schism occurred because of conflict between the so-called liberal theologians in the Chosun Theological Seminary and the conservative leaders in the GA. A representative liberal theologian, Kim Jae Jun, was dismissed from his pastorate. The reason given was that Kim Jae Jun denied the infallibility of the Bible and consequently violated the first article of the Twelve Articles of Faith included in the constitution of the PCK. Opposed to the decision of the GA, Kim Jae Jun and his followers established the Ki Jang Church.

For the theologically conservative PCK, now that the more conservative Ko Shin Church and the very progressive Ki Jang Church, which were relatively small groups, had been severed from the mainline PCK, it seemed that the moderation of the PCK maintained the peace for a while. However, in 1959 the PCK experienced a devastating schism that tore it into two halves of almost the same size, between the party advocating for the World Council of Churches (WCC) and the anti-WCC (or National Association of Evangelicals) party. This schism began with an illegal and morally shameful incident involving a most influential theologian, the principal of the GA (Chonghoi) Presbyterian Theological Seminary, Park Hyung Ryong. Park's followers (of the anti-WCC party) thought of his collapse as their political collapse in the power struggles of the PCK. At that time, the membership of the WCC became an item on the agenda of the GA meeting. The anti-WCC party criticised the WCC and attacked the WCC party by raising questions about its theological liberalism and support of communists and guerrillas. The WCC party regarded the attack of the anti-WCC party as a strategy to escape from its crisis and to maintain its political hegemony in the PCK. This conflict, regardless of attempts at reconciliation, led to a tragic split in the end. The WCC party was called the Tong Hap Church and the anti-WCC party was called the Hap Dong Church.

The fourth schism happened in 1979 in the Hap Dong Church between the mainline GA party and the non-mainline parties. The situation was very complicated and it is difficult to describe it clearly, because a number of parties have come into being since 1979 . Not only pastors in the GA, but also professors and students in the theological seminary complained of the secularisation and corruption of the GA leaders and the illegality of the board of directors of the theological seminary. They requested that the leaders of the GA and theological seminary practise purification. One group of pastors started a new theological seminary, the General Assembly Restoration Seminary, and another group of professors established the Hap Dong Seminary and called itself the Gae Hyuk ('reformed') Church. The group of the General Restoration Seminary, the Hap Dong Bo Su Church, was divided again into the Hongun Party and the Chugdam Party. The Gae Hyuk Church and the Chungdam Party united and called themselves the Gae Hyuk Church, but the union lasted less than a year. Both churches retained the name Gae Hyuk Church. After repeated schisms and reunion, in 1998 nine non-mainline churches dramatically united and called themselves the Gae Hyuk Church, but this unity lasted less than 2 years. By the time of the 2002 GA, there were four Gae Hyuk churches. One group of them, the Gae Hyuk Church (Kwangju), succeeded in reuniting with its mother church, the Hap Dong Church, in 2005, 26 years after their separation. On the other hand, other Gae Hyuk churches are still repeating schisms and reunion.

\section{Analysis and assessment of the disunity in the Presbyterian Church in Korea}

The history of disunity in the PCK shows that a schism took place not because of its laymen or the unimportant pastors of small churches, but because of the main leading figures, influential and powerful leaders who attracted many followers. Whenever a schism occurred, factions formed around a main figure and the decision about schism depended on the main figures, the top responsible leading pastors and theologians in the PCK. In the history of disunity in the PCK, some common factors that played a decisive role in each schism can be seen.

Firstly, generally speaking, the main cause of the disunity was weak recognition of the importance of unity and 
catholicity by the main figures in each factional party - in Van der Borght's words, a weak sense of unity. The majority of the PCK loved the traditional conservative Calvinistic Reformed theology and wanted to be faithful to the word of God and Calvin's teaching. If they had known the truth of God's word on the unity of the church, and if they had known that any conduct contrary to this word of God on unity meant disobedience to God and the serious sin of dividing the body of Christ, they would have prevented the schism, or they would have repented their sin even after the schism. The doctrine of the unity of the church was not emphasised from the pulpit until the tragedy of schism was felt seriously. The word on Christian unity in Ephesians 4:1-16 was preached, taught and heard as the word applied mainly to church members in a local church, and not to the main leaders in a church denomination, let alone a national or worldwide church. Thus the history of disunity in the PCK demonstrated its weak recognition of unity and catholicity, which led to disunity.

Secondly, the PCK was young and immature. The church should grow up to be a mature adult who can maintain unity and peace in truth and love. Fighting and division are evidence of childishness and immaturity. No doubt the influential top leaders were not mature enough to be humble, gentle, patient enough to bear with one another in love, and able to speak the truth in love: Han Sang Dong of the Ko Shin Church (faith of the martyr), Park Hyung Ryong of the Hap Dong Church (conservative Calvinist), Han Gyeong Jik of the Tong Hap Church (WCC-advocating ecumenist) and Jeon Gyu O of the Gae Hyuk Church (conservative Reformed pastor). At the crisis of schism, they were at the centre of division. They did not emphasise the doctrine of unity and catholicity, but rather chose division for the sake of reformation or restoration of the PCK in their own ways. Even though they knew the importance of unity, they justified their own reasons to divide the church, alleging that the opponent party was seriously wrong.

Thirdly, a most serious and dominant cause of division was secularisation of the PCK. As the PCK grew at the denominational level, it became an ecclesiastical political world with hierarchies, hegemony, authority and power, factions, honour, money and self-ambition. The decisive turning point that caused the PCK to secularise was Shinto worship under the Japanese occupation. Voluntary Shinto worshippers could enjoy privileges and high positions as Japanese agents with power and wealth. As pastors tasted and enjoyed the sweetness and pleasures of sin through their connection with worldly power, their sins generally diminished the purity and holiness of the PCK. This endangered the unity of the church.

Just as in the political world, factionalism crept into the polity of the PCK, specifically in the leader-centred faction, for example, theologically the WCC party versus the anti-WCC party, regionally Seoul versus Kwangju. Factionalism and power struggles have traditionally been prevalent in Korean political history, so each party attacked the other in a negative way. They did not know the strategy of win-win and the blessing of togetherness. Even church leaders showed the same tendencies as the world's politicians. Though the cause of division seemed to be a theological difference, in fact all divisions occurred in response to mixed causes, with power struggles for hegemony.

\section{Analysis and assessment of the ecclesiology of the Presbyterian Church in Korea}

I attempt to analyse and assess the ecclesiology of the PCK in relation to the unity, catholicity and ecumenicity of the church.

Firstly, in view of the confession of faith, the PCK confesses the Apostles' Creed in its Sunday worship service. Basically all churches and the church members who believe and confess the Apostles' Creed are in communion with one another and thus they are one and catholic. A problem to be pointed out in confessing the Apostles' Creed is the translation of the article on the church into the Korean language: 'the catholic church' and 'the communion of saints'. To me, the 'catholic church' is heard as 'official, well-organised church', and 'communion' is heard as 'transportation'. This implies that every time church members confess the Apostles' Creed, they recite it without fully understanding its meaning. The original meanings of the terms, 'catholic church' and 'communion of saints', which are important doctrines in relation to unity and catholicity, cannot be envisaged in confessants' minds.

The Nicene Creed as an ecumenical creed (Schaff 1990:12) that professes 'the one holy catholic and apostolic church' clearer than the Apostles' Creed has not been used either in the worship service or in the baptismal catechism. Unity and catholicity are not planted deeply in church members' minds in the PCK.

One of the standard confessions of faith in the PCK from its establishment, the Twelve Articles of Faith (Clark 1918:74-81, 1936:1-10), does not include the article on the church, much less the unity and catholicity of the church.

The Westminster Confession of Faith (WCF) as the doctrinal standard of the PCK that professes the article on the church excellently, according to missionary Dr N.H. Gootjes (2001:368-369, 381) from the Netherlands, has hardly been taught or used well and even tends to be neglected in the PCK.

In the next section, the ministry of the word and the Lord's Supper of the PCK are assessed, based on the two marks of the true church in Calvin's Institutes (Calvin 1960) (4.1.9):

wherever we see the word of God purely preached and heard, and the sacraments administered according to Christ's institution, there, it is not to be doubted, a church of God exists.

Secondly, the first mark of the true church is pure preaching and hearing of the word of God, according to Calvin in his Institutes, namely the ministry of the word of God. In a sense, 
the history of the PCK can be said to be that of the ministry of the word. The PCK has traditionally emphatically regarded the Bible as the word of God and the only infallible rule of faith and practice (Article 1, in the Twelve Articles of Faith of the PCK). The preaching of the word of God is the core part of the Sunday worship service. To make God's word become the rule of members' faith and practice, it has been insisted that believers have to read and meditate on the Bible and to pray in accordance with it personally as an everyday routine, and they have been encouraged to join a weekly Bible study meeting or cell meeting. Even though it is impossible to assess how purely the word of God is preached in every single church or heard by every believer, the apparently remarkable growth of the PCK over approximately one and a half centuries may be the result of emphasis on the ministry of the word and passionate evangelism and world mission. There are many Presbyterian mega-churches in Korea with weekly attendance of over 3000 people at their Sunday worship services. On the other hand, the PCK is in serious disunity and pastors' sins are a big social scandal, for example their misuse of church money, sexual harassment, hereditary succession of mega-church leadership, plagiarism of doctoral dissertations, and so on. This gap between pastors' emphasis on the word of God and their sins indicates that emphasis should be placed not only on the word of individual salvation, but also on that of corporate unity and maturity in terms of mature ecclesiology, and not only on the word of justification as the start of Christian life but also on that of sanctification as a lifetime process in terms of soteriology. The crucial thing is to emphasise the importance of pastors' recognition of and obedience to God's word for the sanctification to holy life and the unity and maturity of the church, rather than their preaching.

Thirdly, one important external means to promote unity and catholicity is the administration of the Lord's Supper as visible word. Even though the PCK has not experienced any schisms on account of the Lord's Supper, its practice is too rare and weak. The PCK, especially pastors and teachers, need to know well the view of the WCF and Calvin on the Lord's Supper, especially on its meaning, effect and frequency. According to Calvin in his Institutes (Calvin 1960) (4.17), the Lord's Supper provides the invisible, spiritual, life-giving food (meal and drink) as a spiritual banquet. By partaking in the Lord's Supper, partakers need to assure themselves of their real, mystical, spiritual union with Christ, their partaking of all Christ's benefits, their spiritual nourishment and growth into one body with Christ and mutual love and bond with Christ and with one another.

Regarding the frequency of the Lord's Supper, Calvin wanted to celebrate it 'very often, and at least once a week' (Calvin 1960) (4.17.43) and critically stated that 'once a year is a veritable invention of the devil' (Calvin 1960) (4.17.46). Even though Calvin favoured weekly celebration of the Lord's Supper, during his ministry at Geneva, the city council refused his plan to celebrate it monthly. Instead it was agreed to celebrate the Lord's Supper four times a year (Ganoczy 2008:11; Horton 2000:149-150; McNeill 1954:160, 164-165; Reid 1954:50).
The practice of the Lord's Supper in the PCK is quite different from Calvin's idea of it. Traditionally the PCK administered the Lord's Supper regularly twice a year, on or around Palm Sunday and on Thanksgiving Sunday. The sermon and explanation of the Lord's Supper at the table usually focused on the crucifixion of Christ in a solemn and sad mood for participants to remember and meditate on the redemptive work and grace of salvation of Christ. Such a practice reflects Zwingli's memorialism rather than Calvin's spiritual presence of Christ at the table. The PCK needs to develop the so-called Calvinistic Eucharistic theology in the sense of promoting unity in the PCK (cf. Horton 2000:148; Nyomi 2010:394).

Fourthly, it is necessary to see what ecumenical efforts have been made to reunite the divided churches and promote the unity of the PCK in view of ecumenicity. Historically the establishment of the PCK was the result of the ecumenical cooperation of the four foreign Presbyterian Missions, as stated earlier. It is important to remember that the PCK started as one Catholic Church. In 1981, around the time that the non-mainline churches began to withdraw from the Hap Dong Church, the five Presbyterian denominations - Tong Hap, Hap Dong, Ko Shin, Ki Jang and Dae Shin - organised the Council of Presbyterian Churches in Korea (CPCK), whose slogan was 'the association and union of the PCK'. For years there was no remarkable progress until 10 July 2009, the 500th birthday of John Calvin. Twenty-six member churches of the CPCK gathered and celebrated the day and decided to celebrate Calvin's birthday as 'the day of the PCK' annually. ${ }^{3}$ All participants in the celebration offered worship service according to Calvin's liturgy and celebrated the Lord's Supper. Even though all Presbyterian denominations did not join in, it was an impressive moment to manifest the oneness of the PCK. Since then, the day of the PCK has become an annual celebration of the CPCK around 10 July, which is Calvin's birthday.

In July 2010 the CPCK made an overture, 'One PCK and multiple denominations', as a practical means to federal union of all the denominations in the PCK. According to this idea, while every denomination of the PCK will maintain its own structure, they will all unite under the United GA of the PCK. The CPCK suggested a road map with five stages: joint prayer meetings, confirmation of the WCF, confirmation of the Westminster directory for the worship of God and form of government, organisation of a committee to draw up the constitution and participation in the Lord's Supper. In December 2012, the draft constitution of the United PCK was proposed to the GA of the CPCK. Among the member churches of the CPCK, the most conservative, the Ko Shin Church, and the most progressive, the Ki Jang Church, came together, which gave the green light for the attainability of unification of the whole PCK in the near future.

One contributing factor is that a faithful Calvinist, Lee Jong Yun, as the originator and the central figure of this movement, 3.All the information about the CPCK was obtained from the Korean weekly newspaper Christian Today. 
has emphasised repeatedly the shameful serious disunity of the PCK in contrast to Calvin's ecumenicity and passionate ecumenical efforts. Whereas efforts for the reunion of divided denominations were generally made with secular intention, such as ecclesiastical expansion in the number of churches and their political strength, Lee's plea was grounded not on secular ambition, but biblical teaching on the unity of the church and Calvin's ecumenicity.

This new paradigm of unity, 'One PCK and multiple denominations', is considered to be a practical solution to the situation of the PCK. In fact, it is inconceivable for more than 200 denominations to unite into one denomination, as the history of disunity has proven. As a long-term process, it is a way to establish a new higher GA (or synod) than the existing GA of each denomination. Even though there are many denominations, they can share brotherly love in Christ and cooperate in diaconal work, common witness, theological education and world mission without rivalry or competition, step by step. In doing so, the CPCK can function as a control tower to coordinate and mediate affairs and problems between denominations. If this cooperation is attained, it will be possible to say that the unity of the PCK is manifested visibly.

Lastly, the relationship with the WCC is a very sensitive issue for the conservative group in the PCK. Before the 1959 schism due to membership of the WCC, the GA of the PCK decided to adopt 'selective participation'. However, the anti-WCC group aggressively attacked the WCC and its advocating pastors. The WCC ironically did not foster the unity of the PCK. The controversy about the WCC arose again within the PCK when the WCC decided to host the 10th Assembly at Pusan, Korea, in November 2013. The Tong Hap Church and the Ki Jang Church are members of the WCC. During that time the relationship between denominations of the PCK was improving through the influence of the $\mathrm{CPCK}$, but the news of the WCC's decision poured cold water on the good relationship between the WCC member churches and the anti-WCC churches in the PCK in a moment. Therefore the WCC deepened the division in the PCK between the WCC member churches and the anti-WCC churches.

One of the reasons for the opposition that the anti-WCC group raised was that the WCC pursued religious pluralism, admitting that other religions also offer salvation. As evidence, the Baar Statement (1990) was referred to. It states that the salvation of God is available in many and various ways outside the fold of Christ. This statement, downgrading Christianity to the level of other religions, is contrary to the gospel of Jesus Christ and enough to provoke the conservative evangelical Reformed churches to holy resentment. It indicates that there are some leading persons who are not faithful to the basic teaching of the Bible in the WCC in evangelical eyes. It is understandable to respect others' religions and faith and their own religious experiences in reciprocal dialogue, but it is an entirely different dimension to identify Christianity with other religions, which do not necessitate the only Redeemer, Jesus Christ (Jn 14:6, Ac 4:12).
If it is possible for sinful humankind to be saved in any way other than by faith in Jesus Christ, the Judaism of the Old Testament was enough for the Jews, and the pagan religions would be enough for the Gentiles. Jesus' death on the cross and resurrection in the New Testament would never have been necessary. Therefore religious pluralism nullifies and destroys Christianity.

Against the anti-WCC group's critique, Byung Joon Jung (2013), a WCC-advocating theologian of the Tong Hap Church, replied in this way:

Critics of the anti-WCC do not use the official documents and position of the WCC but view personal assertions discussed in the theological committee as the official position of the WCC. The WCC has not adopted religious pluralism officially, although the WCC takes an inclusive position in relation to other religions. (p. 125)

Jung's defence is not completely correct, because the WCC explains the nature of the Baar Statement as an official statement in its homepage, 'Resources - Documents: a searchable collection of official WCC documents and statements' (WCC 1990) There is no indication of whether the Baar Statement has been adopted by the GA of the WCC. It could be understood that the Baar Statement is an official document even though it has not been adopted by all the member churches in the GA of the WCC. Only participants in the formulation of the Baar Statement advocate pluralism, yet the WCC accepts it as an official WCC statement. It is not easy to understand this state of affairs. From this, the WCC is seen as an organisation characterised by a mixture of unity, diversity and ambiguity, including even non-biblical factors.

The WCC member churches in the PCK as ecumenical church actively participate in the WCC in the sense that they believe that the WCC can be a helpful instrument to manifest the unity of all Christian churches visibly. By contrast, the antiWCC churches holding to conservative evangelical Reformed theology aggressively oppose the WCC.

Therefore, it is suggested that an ambivalent attitude should be adopted in the relationship with the WCC: 'critical participation'.

If the WCC remains biblical and sticks to its original aim and vision as 'a worldwide fellowship of churches seeking unity, a common witness and Christian service', participation in it is strongly recommended. By contrast, when the WCC practises non-biblical, non-evangelical or non-Christian theology and faith in which the word of God is seriously distorted and replaced with human thoughts and words, it is to be criticised from within rather than from outside.

\section{Suggestions}

Through the study of Ephesians 4:1-16, the doctrine of the unity and catholicity of the church has been clearly affirmed, and the idea of mature ecclesiology has been shaped. To understand the reality of serious disunity of the PCK, 
a historical investigation of the major schisms in the PCK has been conducted. Ecclesiology indicated in traditional theology, faith and church life in the PCK has been analysed and assessed in relation to unity, catholicity and ecumenicity. Now I attempt to make some proposals by integrating the ideas derived from the foregoing discussion for the future of the PCK in particular and Christian churches in general.

To promote the unity of the church, the PCK needs to review weak points in the creeds and confessions of faith in relation to unity and catholicity. The Apostles' Creed needs to translate the article on the Catholic Church and the communion of saints. It would be better to confess and teach the Nicene Creed as an ecumenical creed that professes the one holy catholic and apostolic church' more strongly than the Apostles' Creed. In the Anglican Church the two creeds are used in turn during Sunday worship service. The Twelve Articles of Faith need to be revised to insist on the unity of the church in light of the state of serious disunity of the PCK. In addition, education of the confessions of faith should be emphasised not only in theological schools, but also in local churches.

To restore the seriously divided PCK, a mature sense of unity and mature ecclesiology should be emphasised to the leading figures in all denominations of the PCK. They are primarily responsible for the disunity of the church at the denomination level. They should recognise their weak ecclesiology and weak sense of unity, and furthermore the importance and necessity of unity and maturity in truth and love. There is a need for a balanced perspective between the doctrine of the sevenfold oneness and the practice of the seven graces to unity, and between unity (one church) and purity (pure church), in order to attain unity of faith and knowledge of the Christ, the growth and building up of the church into Christ's full maturity. Without maturity, unity is far from being a reality. Based on the mature sense of unity, the leading figures should make every effort to maintain and manifest unity. When they confront a crisis of division from now on, they should exert a mature sense of unity and avoid further schism. While they grow up, the divided state should be repaired by repentance, reconciliation and reunion.

In relation to the ministry of the word of God as one mark of the true church, pastors should not only preach, but also hear, to obey with emphasis on the corporate unity and maturity of the church, as well as individual salvation in Christian life. This should be accompanied by emphasis on salvation of sanctification as a lifetime process, as well as salvation of justification as the start of Christian life. Consequently, pastors as religious, social leaders and role models, should commit themselves to holy life, spiritual growth and maturity for personal sanctification and the corporate unity and maturity of the church.

The PCK, as Calvin's followers, needs to understand and follow Calvin's view on the Lord's Supper, its spiritual meaning, effect and frequency of celebration. Whenever the Lord's Supper as visible word of God is celebrated, the abundant benefits of spiritual nourishment, growth, fellowship, mutual love and union with Christ and with one another should be declared. Therefore it is suggested that the frequency of celebration of the Lord's Supper should increase to at least four times a year and preferably more, as envisioned by Calvin.

Concerning the unity of the PCK at the national level, it is suggested that all denominations of the PCK actively join and cooperate with the current federal union effort initiated by the CPCK towards 'One PCK and multiple denominations'. While the leading figures of the PCK keep in step with the CPCK, they need to make efforts to reunite with humility, meekness, long-suffering and forbearing one another in love and peace on the basis of the mature ecclesiology in Ephesians $4: 1-16$.

As a general ecumenical guideline for the unity of the church, a roadmap of four stages is offered according to a family concept that the World Alliance of Reformed Churches (WARC) has already drawn up (WARC 1997:162): the unity of the Reformed family, the unity of the broader Christian church and the solidarity of the human family of the whole of creation.

The first stage is the Presbyterian family of churches, with the same confession of faith and the same form of government. All denominations in the PCK should reunite to be the United PCK. The goal of the CPCK, 'One PCK and multiple denominations', is a good path for all denominations to follow.

The second stage is the Reformed family of churches, sharing Calvin's tradition at the national and international levels: Reformed, Presbyterian and Congregational Church. The World Communion of Reformed Churches (WCRC), in which five Presbyterian Churches in Korea have membership, has been making an effort in this direction. ${ }^{4}$

The third stage is the Christian family of churches confessing Jesus Christ as the Lord and Saviour, with the Apostles' Creed as their creed. This category could attain various kinds of visible unity. Erickson (2013:1011-1012) classifies them elaborately: spiritual unity, mutual recognition and fellowship, conciliar unity and organic unity. The WCC's activity falls in this stage.

The last stage is the universal family of God's creation. This category reaches beyond Christianity. However, the command of God is to minister to the world: Christians should love their neighbours, serve and cooperate with other

4.The history of the World Alliance of Reformed Churches is evidence of ecumenical achievements: 'The Alliance of the Reformed Churches throughout the world holding the Presbyterian System' was founded in 1875. In 1970 it merged with the International Congregational Council, which was founded in 1891, into the WARC (Reamonn 1999:28-31). The WARC and the Reformed Ecumenical Council, which was formed in 1946, were united into the WCRC in 2010 (WARC 2009.7-17). Regarding the history of the WCRC, see its homepage at http://wCrc.ch/history The Regarding the history of the WCRC, see its homepage at http://Wcrc.ch/history. The WARC has been involved in bilateral dialogues: Reformed - Roman Catholic, Reformed - Orthodox, Reformed - Oriental Orthodox, Reformed - Pentecostal, and Reformed - Anglican Dialogues (WARC 1997:40-44). A more striking result is a join meeting between Reformed - Lutherans: 'Communion: On Being the Church Report of the Lutheran - Reformed Commission between the Lutheran World Federation (LWF) and the World Communion of Reformed Churches (WCRC), 2006-2012', see the LWF's homepage at https://www.lutheranworld.org. 
religions and humanitarian organisations seeking peace and justice in the world, and make efforts to let all human races hear, know and believe in the Triune God. The WCC also works in this category.

For this goal, it is not suggested that a new church denomination or a new ecumenical body be organised alongside the existing ones, because it will be another divisive action.

\section{Conclusion}

Whereas the PCK as a young, immature church, with 130 years of history, has experienced repeated schisms and is still characterised by serious disunity, weak ecclesiology and a weak sense of unity, the Bible teaches the unity, catholicity and ecumenicity of the church grounded on mature ecclesiology, a mature sense of unity, spiritual growth and maturity.

Investigation of the history of the disunity of the PCK and an assessment of the ecclesiology of the PCK in relation to unity, catholicity and ecumenicity revealed weak points and prompted suggestions to deal with these problems. It is hoped that the PCK in particular and all churches in the world in general will grow into unity and maturity according to biblical teaching, Calvin's thinking and the WCF.

I will end this article with Psalm 133:

How good and pleasant it is when brothers live together in unity!

It is like precious oil poured on the head, running down on the beard, down upon the collar of his robes.

It is as if the dew of Hermon were falling on Mount Zion.

For there the Lord bestows his blessing, even life forevermore.

\section{Acknowledgements Competing interests}

The author declares that he has no financial or personal relationships that may have inappropriately influenced him in writing this article.

\section{References}

Barth, M., [1974] 2008, Ephesians: Introduction, translation and commentary on chapters 1-3, Yale University Press (Assignee from Doubleday), London.

Barth, M., [1974] 2011, Ephesians: Introduction, translation and commentary on chapters 4-6, Yale University Press, London.

Best, E., 1998, A critical and exegetical commentary on Ephesians, T\&T Clark, Edinburgh. Calvin, J., 1960, Institutes of Christian religion, vol. 4, transl. J.T. McNeil, Westminster John Knox, Louisville, KY.
Clark (Gwak), C.A. (ed.), 1918, Jangro Gyohoisa Jeonhwijip (Collections of history of the Presbyterian Church), Chosun Yasogyo Seohoi, Seoul.

Clark (Gwak), C.A. (ed.), 1936, Constitution of the Presbyterian Church of Chosen (Korea), Presbyterian Publication Fund, Seoul.

Danker, F.W., 2000, A Greek - English lexicon of the New Testament and other early Christian literature, 3rd edn., University of Chicago Press, Chicago, IL.

Erickson, M.J., 2013, Christian theology, 3rd edn., Baker Academic, Grand Rapids, MI. Fowl, S.E., 2012, Ephesians: A commentary, Westminster John Knox, Louisville, KY.

Ganoczy, A., 2008, 'Calvin's life', in D.K. McKim (ed.), The Cambridge companion to John Calvin, pp. 3-24, Cambridge University Press, Cambridge.

Gootjes, N.H., (Go), 2001, Dogmatics' theory and practice, Korea Theological Seminary, Cheon An.

Hoehner, H.W., [2002] 2004, Ephesians: An exegetical commentary, Baker Academic, Grand Rapids, MI.

Horton, M.S., 2000, 'At least weekly: The Reformed doctrine of the Lord's Supper and of its frequent celebration', Mid-America Journal of Theology (MJT) 11, 147-169.

Hur, S.G., 2008 (Rev. 2002), A history the Kosin Presbyterian Church in Korea, Young Moon Publishing, Seoul.

Jung, B.J., 2013, 'A historical survey on the recent critique on the WCC', in The 10th Assembly of the WCC and ecumenical movement of the Korean Church, pp. 118-125, The GAPCK, Seoul.

Kang, M.S. Ko, G.S., So, G.S., Lee, W.J., Han, G.S. \& Hwang, Y.S. (eds.), 2015, History of the reformed Presbyterian Church in Korea 1979-2005, Kwangsin University Publisher, Kwangju.

Lincoln, A.T., 1990, Word Biblical Commentary volume 42 Ephesians, Word Books, Texas.

Lutheran World Federation, 2015, Communion: On being the Church: Report of the Lutheran - Reformed Commission between the Lutheran World Federation (LWF) and the World Communion of Reformed Churches (WCRC), $2006-2012$, viewed 17 July 2015, from http://www.lutheranworld.org/content/lutheran-reformeddialogue

McNeill, J.T., 1954, The history and character of Calvinism, Oxford University Press, New York.

Nyomi, S., 2010, 'Covenanting for justice - Where would Calvin stand?', Nederduitse Gereformeerde Teologiese Tydskrif (NGTT) Deel 51. Supplementum, 390-396. (Teologie $150+$ en CALVYN 500).

O'Brien, P.T., 1999, The letter to the Ephesians, Wm. B. Eerdmans, Grand Rapids, MI.

Park, Y.G., [2004a] 2007, History of the Korean Church 1 (1784-1910), Word of Life, Seoul.

Park, Y.G., [2004b] 2006, History of the Korean Church 2 (1910-1960).Word of Life, Seoul.

Reamonn, P. (ed.), 1999, Introducing the world alliance of reformed churches, WARC, Geneva.

Reid, J.K.S. (transl.), 1954, Calvin: Theological treatises, The Westminster Press, Philadelphia, PA.

Schaff, P. (ed.), 1990, The Creeds of Christendom with a history and critical notes volume 1, reprint from 1931, 6th edn., Baker Book House, Michigan.

Schnackengburg, R., 1991, Ephesians: A commentary, transl. H. Heron, T \& T Clark, Edinburgh.

Thielman, F., 2010, Ephesians: Baker exegetical commentary on the New Testament, Baker Academic, Grand Rapids, MI.

Van der Borght, E. (ed.), 2010, The unity of the church: A theological state of the art and beyond, Koninklijke Brill NV, Leiden.

World Alliance of Reformed Churches, 1997, From Seoul to Debrecen: Break the chains of injustice, WARC, Geneva.

World Alliance of Reformed Churches, 2009, From Accra and Utrecht to Grand Rapids 2004-2010: Moving towards unity 2010 uniting general council, WARC, Geneva.

World Communion of Reformed Churches, 2015, WCRC history, viewed 16 July 2015 , from http://wcrc.ch/history

World Council of Churches, 1990, Baar Statement, viewed 03 July 2015, from http:// www.oikoumene.org/en/resources/documents/wcc-programmes/interreligiousdialogue-and-cooperation/christian-identity-in-pluralistic-societies/baarstatement-theological-perspectives-on-plurality

Yang, N.H., 2008, A history of the Korean Presbyterian Church, Word of Life, Seoul. 